Bull. Chem. Soc. Ethiop. 2019, 33(2), 191-202.

ISSN 1011-3924

(c) 2019 Chemical Society of Ethiopia and The Authors

Printed in Ethiopia

DOI: https://dx.doi.org/10.4314/bcse.v33i2.1

\title{
ASSESSMENT ON THE LEVELS OF SELECTED ESSENTIAL AND NON- ESSENTIAL METALS IN SESAME SEEDS (SESAMUM INDICUM L.) COLLECTED FROM SHERARO TOWN, NORTHWEST TIGRAY, ETHIOPIA
}

\author{
Abraha Gebrekidan* and Atsbha Abadi Desta \\ Department of Chemistry, College of Natural and Computational Sciences, Mekelle University, \\ P.O. Box 231, Mekelle, Ethiopia
}

(Received November 23, 2018; Revised April 24, 2019; Accepted April 29, 2019)

\begin{abstract}
The purpose of this study was to determine the levels of essential and non-essential metals in sesame seeds (Sesamum indicum L.). Six sesame seed samples (three red and three white) were purchased randomly from six shops in Sheraro, Tigray, Ethiopia. The levels of $\mathrm{Fe}, \mathrm{Zn}, \mathrm{Cu}, \mathrm{Cd}$ and $\mathrm{Pb}$ in the sesame samples were determined by FAAS. $5 \mathrm{~g}$ of dried and homogenized samples were digested using $30 \mathrm{~mL}$ of $\mathrm{HNO}_{3}(70 \%)$ and $25 \mathrm{~mL}$ of $\mathrm{HCl}(37 \%)$ at $120^{\circ} \mathrm{C}$ for 5 hours. The efficiency of the procedure was validated by spiking and the percent recovery for all studied metals varied from $90-120 \%$. The mean levels of the metals $(\mathrm{mg} / \mathrm{kg}) \mathrm{were}$ found in the ranges 35.5-43.1, 58.1-67.0, 15.3-21.3, 0.202-0.262 and 0.08-0.114 for $\mathrm{Fe}, \mathrm{Zn}, \mathrm{Cu}, \mathrm{Cd}$ and $\mathrm{Pb}$, respectively. Analysis of variance at $95 \%$ confidence level indicated significant variations only for $\mathrm{Cu}$ and $\mathrm{Zn}$. Thus, the sesame seeds analyzed are safe for human consumption.
\end{abstract}

KEY WORDS: Sesamum indicum L., Essential metals, Non-essential metals, FAAS, Shiraro, Tigray (Ethiopia)

\section{INTRODUCTION}

Sesame seeds (Sesamum indicum L.) are one of the edible seeds. Sesame seeds are probably the most ancient oilseed cultivated in several countries such as India, Sudan, China, Ethiopia and Burma which are considered as the major producers $(60 \%$ of its total world production) $[1,2]$.

Currently, food safety is considered to be one of the concerns of consumers of developed and developing countries. In the last decades, an increasing demand for food safety has initiated research works regarding the risk associated with consumption of foodstuffs contaminated by pesticides, heavy metals and/or toxins [3]. Thus, food safety issues and its subsequent problems are among the serious public and environmental concerns. Heavy metal accumulations in plants depend upon plant species and their efficiencies in absorbing metals, which is also evaluated by either plant uptake or soil to plant transfer factors of the metals [4]. Toxic heavy metals are given due attention due to their toxicity and mutagenic effects even at very low concentration [5, 6]. Preventing food items from heavy metal contamination is therefore one of the important aspects of food quality assurance. Accordingly, the content of micro-essential and non-essential heavy metals in sesame (Sesamum indicum L.) is of great interest to consumers [7].

Micro-elements play important roles in chemical, biological, biochemical, metabolic, catabolic and enzymatic reactions in the living cells of plants, animals and human beings [8]. Among these, zinc is found in several enzymes and involved in genetic material transcription [9]. Copper is also a key component of oxidation-reduction enzymes [10]. Iron is vital in oxygen transport and also enables metabolism [11]. These micro-elements are required in very small amounts. Otherwise, their deficiency causes diseases and their presence in excess results in toxicity to human life by disturbing the normal functioning of organs and central nervous system [8]. For instance, anemia which affects more than half of pregnant women and at least one third of children under five years is caused by the deficiency of iron [12]. Metals like lead and cadmium are among the non-essential heavy metals and are particularly toxic. Both metals cause adverse health effects in humans, and their widespread presence in the human environment

*Corresponding author. abrishgk@yahoo.com

This work is licensed under the Creative Commons Attribution 4.0 International License 
comes from natural and anthropogenic activities [13]. Cadmium has been considered as an extremely significant pollutant, even in small amounts, affecting all forms of life because of its high toxicity and great solubility in soil and water [14, 15]. Studies indicated that highest cadmium concentrations are found in rice, wheat, oyster, mussels, and the kidney cortex of animals [16]. Lead is also a well-documented metal toxicant and its exposure leads to many fatal diseases, including the dysfunction of renal blood and neurological systems [17]. No level of lead in blood should be considered safe for children due to its neurotoxicity [14, 15]. Studies also indicated that the effect of lead is similar to that of cadmium [18]. Thus, because of their possible health effects it is important to control the level of these toxic elements in food, especially in products, which are known to have beneficial effects on public health.

Sesame crop production is the major farming system in the western part of Tigray, Ethiopia. Thus, sesame is one of the export crops in Ethiopia. This attracts the agricultural areas to be covered by sesame and ultimately boosts its production due to the attractive prices in the export market. The presence of toxic heavy metals in sesame crops affect its quality and ultimately will hamper the attraction of hard currency for the country. But, the survey of literature showed that no study has been reported on the levels of metals in Sesamum indicum L. which is found in Shiraro, northwest of Tigray, Ethiopia. This initiates an interest to determine the levels of essential and non-essential metals in sesame seeds. Therefore, the main objectives of this study were to determine the levels of essential $(\mathrm{Fe}, \mathrm{Zn}$ and $\mathrm{Cu})$ and non-essential metals $(\mathrm{Cd}$ and $\mathrm{Pb})$ in Sesamum indicum L. which is commercially available in Shiraro town, Tigray, Ethiopia; compare the levels of these metals in red and white sesame seed samples; and compare the levels of these metals with values reported in the literatures.

\section{EXPERIMENTAL}

\section{Reagents and chemicals}

During the study $70 \% \mathrm{HNO}_{3}(\mathrm{BDH}$, England) and $37 \% \mathrm{HCl}$ (Riedel-de Haen, Germany) were used for the digestion of sesame seed samples. Stock standard solutions containing $1000 \mathrm{mg} / \mathrm{L}$, in $2 \% \mathrm{HNO}_{3}$, of the metals $\mathrm{Fe}, \mathrm{Zn}, \mathrm{Cu}, \mathrm{Cd}$, and $\mathrm{Pb}$ (SPECTROSCAN, Industrial Analytical Ltd, South Africa) were used for the preparation of calibration standards and spiking experiments. De-ionized water was used throughout the experiments for sample preparation, dilution and rinsing apparatus prior and during analysis. The reagents used during the analysis were all of analytical grade.

\section{Instruments}

The sesame seed samples were washed with deionized water and then dried in an oven (FED 53, USA). Mortar and pestle were also used to grind and powder the dried sesame seed samples. A digital analytical balance (Mettle Toledo, Model AG204, Switzerland) with $+0.0001 \mathrm{~g}$ precision was used to weigh the sesame seed samples. The dried and powdered sesame seed samples were digested in hot plate using $100 \mathrm{~mL}$ beaker in the laboratory.

The essential and non-essential metals $(\mathrm{Fe}, \mathrm{Zn}, \mathrm{Cu}, \mathrm{Cd}$ and $\mathrm{Pb}$ ) were determined using a Varian AA240 FS Fast Sequential Atomic Absorption Spectrophotometer (FAAS) (Varian, Australia), fully automated and PC-controlled using Apectra AA Base and PRO software versions equipped with fast sequential operation for multi-element flame determinations with four lamp positions and automatic lamp selection. A deuterium background corrector was used for background corrections. For flame measurements, a $10 \mathrm{~cm}$ long slot-burner head, a lamp and an air-acetylene flame were used. The operating parameters of FAAS for the elements determined in this study are presented in Table 1. 
Table 1. Working conditions of air- $\mathrm{C}_{2} \mathrm{H}_{2}$ flame atomic absorption spectroscopy, FAAS.

\begin{tabular}{|c|c|c|}
\hline Element & Wavelength, $\mathrm{nm}$ & Instrument detection limit, $\mathrm{mg} / \mathrm{L}$ \\
\hline $\mathrm{Cd}$ & 228.8 & 0.002 \\
\hline $\mathrm{Pb}$ & 217.0 & 0.01 \\
\hline $\mathrm{Cu}$ & 324.8 & 0.003 \\
\hline $\mathrm{Zn}$ & 213.9 & 0.001 \\
\hline $\mathrm{Fe}$ & 248.3 & 0.006 \\
\hline
\end{tabular}

\section{Description of the study area}

The study was conducted in Sheraro town which is found in Northwest Tigray, Northern Ethiopia, $1140 \mathrm{~km}$ far from Addis Ababa and $357 \mathrm{~km}$ away from Mekelle town, the capital city of Tigray Regional State. It is found between $14^{\circ} 24^{\prime} 00^{\prime \prime} \mathrm{N}$ latitude and $37^{\circ} 56^{\prime} 00^{\prime \prime} \mathrm{E}$ longitude with altitude of $1,246 \mathrm{~m}$ above sea level (Figure 1). The area is characterized by a mean annual temperature range of $26-39{ }^{\circ} \mathrm{C}$, receiving an annual mean rainfall of $29 \mathrm{~mm}$. The town has a total population of 24,246 and 7,131 households [19]. The major economic activity of the town is subsistence agriculture and mainly accounts to cereal production and animal husbandry.

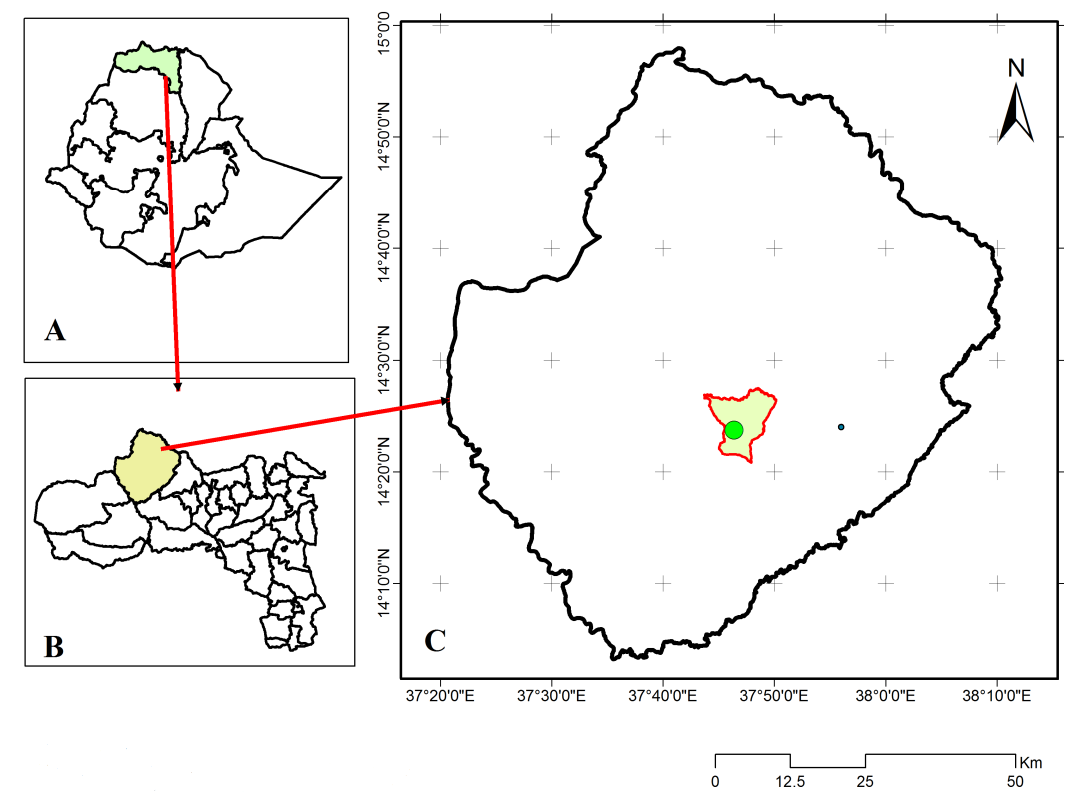

Figure 1. Map of the study area: A) Ethiopia; B) Tigray; C) Sheraro.

\section{Collection of samples}

Sesame seed samples were purchased randomly from six shops (three red and three white sesame seeds) in Sheraro town, Northwest Tigray, Northern Ethiopia. The samples were packed into six polyethylene plastic container bags, labeled and transported to the Ezana Mining development P.L.C Analytical Laboratory (Mekelle, Tigray, Ethiopia) for further treatment and analysis. 


\section{Sample preparation for elemental analysis}

The sesame seed samples were washed with tap water and there after rinsed in de-ionized water so as to remove surface contaminants like soil, dust, spray residues and sun dried. Stones and other wastes were removed manually from sesame seed samples. The samples were placed in acid washed clean aluminum pans labeled according to the sample and oven dried at $105^{\circ} \mathrm{C}$ for 48 hours in drying oven until they reached constant weight. Next, the dried sesame seed samples grounded and homogenized into fine powder using mortar and pestle and sieved using $0.3 \mathrm{~mm}$ sieve to obtain fine powder which is appropriate for digestion. Then after, the fine powder of sesame seed samples were kept in polyethylene plastic bags until the samples were taken for digestion.

\section{Digestion of sesame seed samples}

For digestion with wet ashing, $5 \mathrm{~g}$ of dried, powdered and homogenized sesame seed samples of approximately $0.3 \mathrm{~mm}$ in size were transferred into $100 \mathrm{~mL}$ beakers. Wet digestions of the samples were performed by using mixtures of two acids: $\mathrm{HNO}_{3}(70 \%)$ and $\mathrm{HCl}(37 \%)$. First, 30 $\mathrm{mL}$ of Conc. $\mathrm{HNO}_{3}$ was added to a $5.0 \mathrm{~g}$ sample and the mixture was digested at a temperature of $120^{\circ} \mathrm{C}$ for 5 hours until 3 to $6 \mathrm{~mL}$ of digest remained. Then, $25 \mathrm{~mL}$ of Conc. $\mathrm{HCl}(37 \%)$ was added. The heat was increased to boil the sample until 10 to $15 \mathrm{~mL}$ of volume remained. After cooling, $15 \mathrm{~mL}$ of de-ionized water was added and then the residue was filtered through Whatman No. $42(75 \mu \mathrm{m}$ size) filter paper and diluted to $50 \mathrm{~mL}$ with de-ionized water. Five blank solutions were also prepared following the same digestion procedure as the samples [20].

\section{Analytical procedures}

Before the analysis of heavy metals in the sesame seed samples, calibrations of the instrument with the known concentration of standards were done for each metal of interest $(\mathrm{Fe}, \mathrm{Zn}, \mathrm{Cu}, \mathrm{Cd}$ and $\mathrm{Pb}$ ). First, $20 \mathrm{mg} / \mathrm{L}$ intermediate standard solutions of each metal were prepared from the stock solutions $(1000 \mathrm{mg} / \mathrm{L})$. The working standards were prepared from the intermediate standard solutions using serial dilutions. The intermediate standard solutions were diluted with deionized water to obtain three working standards for each metal of interest (Table 2). Then after, analyses of the sesame seed samples were performed after determining the detection limits and validating the procedures with recovery tests [21]. Finally, samples were taken by $16 \times 150$ $\mathrm{mm}$ test tubes and the levels of essential $(\mathrm{Fe}, \mathrm{Zn}$ and $\mathrm{Cu})$ and non-essential $(\mathrm{Cd}$ and $\mathrm{Pd})$ metals were determined directly in the extract solution using FAAS.

\section{Instrument calibrations}

The instrument used for analysis, FAAS, was calibrated using three series of working standards for each metal of interest. Triplicate readings were taken for each working standard solutions. The correlation coefficients obtained for the calibration curves for $\mathrm{Fe}, \mathrm{Zn}, \mathrm{Cu}, \mathrm{Cd}$ and $\mathrm{Pb}$ were $0.9998,0.9892,0.9989,0.9988$ and 1.0000 , respectively confirming a very good positive correlation between the absorbance and the concentration and the working solutions were linearly fitted. Finally, the same analytical procedure was used for the determination of elements in the digested blank and sample solutions.

\section{Method performance and validation}

Method validation is the process used to confirm the analytical procedure employed for a specific test to be suitable for its intended use. Results from method validation can also be used to judge the quality, reliability and consistency of analytical results; and it is considered as an 
integral part of any good analytical practice [22]. The parameters: accuracy, precision, sensitivity, limit of detection were used for method validation [23, 24].

Accuracy

The accuracy and validity of the measurement were determined by analyzing spiked samples using standard solutions with triplicate measurements.

\section{Precision}

In this study the precision of the results were evaluated by the standard deviation (SD) values. Triplicate readings were taken for each sample. Thus, in this work the data are reported as mean $\pm \mathrm{SD}, \mathrm{mg} / \mathrm{L},(\mathrm{n}=6)$ to show the degree of precision.

\section{Limit of detection (LOD)}

In the present study, limit of detection (LOD) for the metals were estimated by digesting five analytical blanks following the same procedure used for sesame seed samples. Triplicate readings of the five blank samples for each interest of metals were performed and the pooled standard deviations of the five blank reagents were calculated. Finally, the detection limits were obtained by multiplying the standard deviation of the reagent blank $\left(\mathrm{s}_{\mathrm{B}}\right)$ by three $\left(\mathrm{LOD}=3 \mathrm{~s}_{\mathrm{B}}, \mathrm{n}\right.$ =3) [25].

\section{Validation of the procedure}

The efficiency of the procedure can be checked by various methods. Among these, the use of certified standard reference material for analyses and spiking the sample with known concentration of the analyte are common. Thus, in this work the validation of the procedure was established by spiking experiments. The spiked samples were prepared by adding a small known quantity of metal standard solutions. For spiking sesame seed sample, $6 \mathrm{~mL}$ of $5.0 \mathrm{mg} / \mathrm{L} \mathrm{Fe}, \mathrm{Cu}$, $\mathrm{Zn}, \mathrm{Pb}$ and $\mathrm{Cd}$ standard solutions were added to a $250 \mathrm{~mL}$ beaker containing $5 \mathrm{~g}$ ground sesame seed sample. The spiked and non-spiked samples were digested and analyzed with the same procedure following the procedure used for the analysis of sesame seed samples.

\section{Statistical analysis}

All data were statistically analyzed by evaluating the mean and standard deviation. Mean values obtained for the elemental concentrations of sesame seed samples were compared by One-Way ANOVA using SPSS 20.0 for Windows. Level of significance was set at $\mathrm{p}<0.05$.

\section{RESULTS AND DISCUSSION}

\section{Instrument calibration}

Calibration curves were used to understand the instrumental response to the metal analyzed and predict the concentration in an unknown sample. Accordingly, a set of standard solutions were prepared at various concentrations with a range that includes the unknown of the metal concentration. In this regard, concentrations of the working standards, analytical wavelengths, regression equation, and value of correlation coefficient for each analyzed metal are summarized in Table 2. The correlation coefficients $\left(\mathrm{R}^{2}\right)$ for the calibration curves were obtained in the ranges of 0.9892 to 1.0000 indicating that there was a very high correlation 
(relationship) between concentration and absorbance [26]. Therefore, the method employed for the analysis of metals in sesame samples was acceptable.

\section{Precision}

As it is indicated in Table 4, the relative standard deviations were obtained less than $10 \%$ for all elements. Thus, the precision of the procedure revealed the closeness or agreement of replicate measurements analyzed by using FAAS.

\section{Limits of Detection (LOD)}

The LOD values for $\mathrm{Fe}, \mathrm{Cu}, \mathrm{Zn}, \mathrm{Pb}$ and $\mathrm{Cd}$ elements are given in Table 2. Thus, the results obtained for the five metals of interest detected in the sesame seed samples were above detection limits.

\section{Recovery test of the procedure}

The efficiency of the digestion procedure was checked by spiking methods. Thus, the results of recovery tests for the studied metals are presented in Table 3 .

Table 2. Analytical wavelengths, working standards, correlation coefficients and correlation equations of the calibration curves, instrument detection limit and method detection limit for determinations of heavy metals using FAAS.

\begin{tabular}{|c|c|c|c|c|c|c|}
\hline Metal & $\begin{array}{c}\text { Wavelength } \\
(\mathrm{nm})\end{array}$ & $\begin{array}{c}\text { Concentration of } \\
\text { working } \\
\text { standards }(\mathrm{mg} / \mathrm{L})\end{array}$ & $\begin{array}{c}\text { Correlation coefficient } \\
\text { of } \\
\text { calibration curves }\left(\mathrm{R}^{2}\right)\end{array}$ & $\begin{array}{c}\text { Equation for calibration curves } \\
(\mathrm{A}=\mathrm{mC}+\mathrm{b})\end{array}$ & $\begin{array}{c}\mathrm{IDL} \\
(\mathrm{mg} / \mathrm{L})\end{array}$ & $\begin{array}{c}\mathrm{MDL}^{* *} \\
(\mathrm{mg} / \mathrm{L})\end{array}$ \\
\hline $\mathrm{Fe}$ & 248.3 & $2,5,10$ & 0.9998 & $\mathrm{~A}=0.063 \mathrm{C}+0.184$ & 0.006 & 0.02 \\
\hline $\mathrm{Zn}$ & 213.9 & $5,10,20$ & 0.9892 & $\mathrm{~A}=0.033 \mathrm{C}+0.16$ & 0.003 & 0.03 \\
\hline $\mathrm{Cu}$ & 324.8 & $5,10,20$ & 0.9989 & $\mathrm{~A}=0.027 \mathrm{C}+0.022$ & 0.001 & 0.20 \\
\hline $\mathrm{Cd}$ & 228.8 & $0.5,1.0,2.0$ & 0.9988 & $\mathrm{~A}=0.175 \mathrm{C}+0.034$ & 0.010 & 0.05 \\
\hline $\mathrm{Pb}$ & 217.0 & $0.5,1.0,2.0$ & 1.0000 & $\mathrm{~A}=0.034 \mathrm{C}$ & 0.002 & 0.02 \\
\hline
\end{tabular}

${ }^{*} \mathrm{~A}=$ absorbance, $\mathrm{C}=$ concentration in $\left.\mathrm{mg} / \mathrm{L}\right),{ }^{*} \mathrm{IDL}=$ instrument detection limit; ${ }^{* *} \mathrm{MDL}=$ method detection limit.

Table 3. Recovery test for the procedure of sesame seed samples

\begin{tabular}{|c|c|c|c|c|}
\hline Metal & $\begin{array}{c}\text { Conc. of metal in } \\
\text { the un-spiked } \\
\text { sample }(\mathrm{mg} / \mathrm{L})\end{array}$ & $\begin{array}{c}\text { Amount } \\
\text { added }(\mathrm{mg} / \mathrm{L})\end{array}$ & $\begin{array}{c}\text { Conc. of metal in the spiked 5 g sample } \\
(\mathrm{mg} / \mathrm{L})\end{array}$ & $\begin{array}{c}\text { Percent } \\
\text { recovered }(\% \mathrm{R})\end{array}$ \\
\hline $\mathrm{Fe}$ & $35.2 \pm 0.41$ & 5 & $41.2 \pm 0.11$ & 120 \\
\hline $\mathrm{Cu}$ & $20.4 \pm 0.38$ & 5 & $24.9 \pm 0.06$ & 90.0 \\
\hline $\mathrm{Zn}$ & $63.6 \pm 0.57$ & 5 & $68.7 \pm 0.36$ & 101 \\
\hline $\mathrm{Pb}$ & $0.08 \pm 0.01$ & 5 & $5.25 \pm 0.12$ & 104 \\
\hline $\mathrm{Cd}$ & $0.27 \pm 0.01$ & 5 & $5.20 \pm 0.02$ & 98.7 \\
\hline
\end{tabular}

The results of percent recoveries of the heavy metals in the spiked sesame seed samples were ranged from $90-120 \%$, which falls within the acceptable range of recoveries $(80-120 \%)$ [27]. Thus, good recoveries were obtained for all interest of the studied metals indicating that a good accuracy was obtained for the employed procedures. Therefore, the laboratory performance for each analyte was under control showing that the method was efficient. Recovery values recorded in the above range was acceptable for metal analysis because the digestion procedure is believed to remove metal fractions associated with organic matter [28]. The lower recovery recorded for copper may be due to incomplete digestion of the sesame seed 
samples while the high recovery (excess recovery) value of iron could be attributed due to contamination of the sesame seed samples.

\section{Levels of essential and non-essential metals in sesame seed samples}

The mean levels of essential $(\mathrm{Fe}, \mathrm{Zn}$ and $\mathrm{Cu})$ and non-essential $(\mathrm{Pb}$ and $\mathrm{Cd})$ metals (mean $\pm \mathrm{SD})$ obtained from the red and white sesame seed samples are summarized in Table 4.

Table 4. Average concentration (mean $\pm \mathrm{SD}, \mathrm{mg} / \mathrm{kg}$, dry wt.) of essential and non-essential heavy metals of sesame seeds samples $(\mathrm{N}=3)$; average means followed by same letter in the same column are not significantly different at $\mathrm{p}<0.05$.

\begin{tabular}{|c|c|c|c|c|c|c|}
\hline \multirow[t]{2}{*}{ Sample type } & \multirow[t]{2}{*}{ Sample } & Concentration & Concentration & Concentration & Concentration & Concentration \\
\hline & & $\mathrm{Fe}$ & $\mathrm{Zn}$ & $\mathrm{Cu}$ & $\mathrm{Cd}$ & $\mathrm{Pb}$ \\
\hline \multirow{3}{*}{ 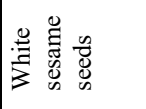 } & *Sample-1 & $41.6 \pm 0.01$ & $61.9 \pm 0.86$ & $17.2 \pm 0.01$ & $0.20 \pm 0.00$ & $0.15 \pm 0.01$ \\
\hline & *Sample-2 & $36.0 \pm 0.48$ & $60.7 \pm 0.16$ & $15.3 \pm 0.02$ & $0.22 \pm 0.00$ & $0.16 \pm 0.01$ \\
\hline & *Sample-3 & $37.5 \pm 0.32$ & $57.9 \pm 0.34$ & $18.9 \pm 0.05$ & $0.23 \pm 0.00$ & $0.11 \pm 0.01$ \\
\hline \multicolumn{2}{|c|}{$\begin{array}{l}\text { Average of white sesame } \\
\text { seeds }\end{array}$} & $38.4 \pm 0.27^{\mathrm{a}}$ & $60.2 \pm 0.45^{\mathrm{a}}$ & $17.1 \pm 0.03^{\mathrm{a}}$ & $0.22 \pm 0.00^{\mathrm{a}}$ & $0.14 \pm 0.01^{\mathrm{a}}$ \\
\hline \multirow{3}{*}{ 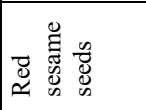 } & **Sample-1 & $43.1 \pm 0.29$ & $67.3 \pm 1.97$ & $21.3 \pm 0.16$ & $0.20 \pm 0.00$ & $0.14 \pm 0.01$ \\
\hline & **Sample-2 & $39.2 \pm 0.38$ & $63.8 \pm 0.04$ & $19.8 \pm 0.13$ & $0.21 \pm 0.00$ & $0.14 \pm 0.01$ \\
\hline & **Sample-3 & $35.2 \pm 0.16$ & $63.6 \pm 0.32$ & $20.4 \pm 0.14$ & $0.27 \pm 0.00$ & $0.08 \pm 0.00$ \\
\hline \multicolumn{2}{|c|}{ Average of red sesame seeds } & $39.1 \pm 0.28^{\mathrm{a}}$ & $64.9 \pm 0.78^{b}$ & $20.5 \pm 0.14^{\mathrm{b}}$ & $0.23 \pm 0.00^{\mathrm{a}}$ & $0.12 \pm 0.01^{\mathrm{a}}$ \\
\hline
\end{tabular}

*- White sesame seeds, ${ }^{* *}$ - Red sesame seeds.

Iron is an essential element in human body metabolism acting as a catalyst and its acceptable limit for human consumption is 80 to $110 \mathrm{mg} / \mathrm{L}$ [29]. In the absence of enzymatic catalysis, most biochemical reactions are so slow that they would not occur under the mild conditions of temperature and pressure that are compatible with life [30]. The iron content obtained from sesame samples was ranged from 35.2 to $43.1 \mathrm{mg} / \mathrm{kg}$, which is below the recommended safety limits for consumption (80 to $110 \mathrm{mg} / \mathrm{L}$ ) [29]. Therefore, sesame seeds which contain iron can be consumed without any health problems. In this study, the results of ANOVA analysis also showed that there were no any significantly differences between the red and white sesame samples in their iron contents.

Zinc is also an important element in human body which is needed for the proper work of the immune systems. It plays a great role in cell division, cell growth, wound healing, and the catabolism of carbohydrates [31]. The level of zinc is present in greater amounts than other elements analyzed. The acceptable limit for human consumption of zinc is $150 \mathrm{mg} / \mathrm{L} \mathrm{[32].} \mathrm{The}$ mean levels of $\mathrm{Zn}$ in the analyzed sesame seed samples were within the range of 57.9 to 67.3 $\mathrm{mg} / \mathrm{kg}$, which is below the recommended safety limit for human consumption. Therefore, sesame seeds which contain zinc can be consumed without any health risks. In this regard, higher level of $\mathrm{Zn}$ in red sesame sample $(64.9 \pm 0.78 \mathrm{mg} / \mathrm{kg})$ was obtained than the white sesame sample $(60.2 \pm 0.45 \mathrm{mg} / \mathrm{L})$ which was significantly different at $95 \%$ confidence level. This could be due to the fact that micronutrients are significantly affected by soil $\mathrm{pH}$ and decreased with increasing soil $\mathrm{pH}$ [33]. Other findings also indicated that mineral fertilization with nitrogen contributed to a decrease of soil $\mathrm{pH}$ and thus enhances mobility of some metals like $\mathrm{Zn}[34,35]$. Thus, the difference in the levels of $\mathrm{Zn}$ metal could be due to the differences on the nature of soil composition and soil $\mathrm{pH}$.

Copper is also an essential element which is necessary for normal biological activities of amino-oxides and tyrosinase enzymes [8]. Therefore, certain amount of copper is vitally necessary for human beings. The acceptable limit for human consumption of copper is 20.4 $\mathrm{mg} / \mathrm{L}$ [29]. The present investigation showed that the mean levels of copper varied from 15.3 to 
$21.3 \mathrm{mg} / \mathrm{L}$, which is found slightly below the safety limit set for copper consumption. Thus, our findings indicated that sesame seeds which contain copper can be consumed without any health problems for human. This study also indicated that the red sesame seed samples $(20.5 \pm 0.14$ $\mathrm{mg} / \mathrm{kg}$ ) was obtained in higher concentration of copper than the white sesame seed samples $(17.1 \pm 0.03 \mathrm{mg} / \mathrm{kg})$ which is significantly different at $95 \%$ confidence level. This could be due to the differences in soil $\mathrm{pH}$ and soil composition where the sesame seeds grown [35].

Cadmium is a severe pulmonary and gastrointestinal irritant, which can be fatal if inhaled or ingested [36] and is classified as human carcinogen by several regulatory agencies $[37,38]$. The permissible limit for cadmium in foods is $0.5 \mathrm{mg} / \mathrm{L}$ [39]. In the present investigation, the mean levels of $\mathrm{Cd}$ in the analyzed sesame seed samples were within the ranges of 0.20 to $0.27 \mathrm{mg} / \mathrm{kg}$, which is below the safety limit set for cadmium consumption. Therefore, the local sesame seeds can be consumed without any health problems for human consumptions. The results of ANOVA analysis also showed that there were no any significance differences in the amounts of $\mathrm{Cd}$ between the red and white sesame seed samples.

Lead is one of the chemical pollutants of the environment and is known to be toxic to human being [36]. In the present study, the lead content varied from 0.08 to $0.16 \mathrm{mg} / \mathrm{kg}$, which is recorded below the safety limit $(2 \mathrm{mg} / \mathrm{L})$ set for human consumption [40]. Thus, the local sesame seeds can be consumed without any health risks. The results of ANOVA analysis also indicated that there were no any significant differences in the amounts of $\mathrm{Pb}$ between the red and white sesame seed samples. In general, the trend of concentrations of essential and nonessential heavy metals in sesame seeds studied in this work is recorded in the order of $\mathrm{Zn}>\mathrm{Fe}$ $>\mathrm{Cu}>\mathrm{Cd}>\mathrm{Pb}$.

Comparison of the mean levels of studied metals with literature data

Comparison on the levels of the studied essential and non-essential metals in sesame samples of this study has been made with literature values (Table 5).

Table 5. Comparison of range of mean values of the studied metals in Sesame seeds with literature value.

\begin{tabular}{|c|c|c|c|c|c|c|}
\hline \multirow{2}{*}{ Country } & \multicolumn{5}{|c|}{ Mean values of studied metals $(\mathrm{mg} / \mathrm{kg})$} & Reference \\
\cline { 2 - 7 } & $\mathrm{Fe}$ & $\mathrm{Cu}$ & $\mathrm{Zn}$ & $\mathrm{Pb}$ & $\mathrm{Cd}$ & \\
\hline Ethiopia & $35.2-43.1$ & $15.3-21.3$ & $57.9-67.3$ & $0.08-0.16$ & $0.20-0.27$ & This study \\
\hline Iran & $\mathrm{NR}^{*}$ & $\mathrm{NR}^{*}$ & $\mathrm{NR}^{*}$ & 0.0516 & 0.0157 & {$[20]$} \\
\hline Ethiopia & $102-108$ & $\mathrm{NR}^{*}$ & $42.3-44.5$ & $\mathrm{NR}^{*}$ & $\mathrm{NR}^{*}$ & {$[41]$} \\
\hline Nigeria & 113 & 20.4 & 93.2 & $\mathrm{NR}^{*}$ & $\mathrm{NR}^{*}$ & {$[42]$} \\
\hline Turkey & $63.3-254$ & $15.1-19.8$ & $28.3-36.3$ & $\mathrm{NR}^{*}$ & $\mathrm{NR}^{*}$ & {$[43]$} \\
\hline
\end{tabular}

As it can be seen from Table 5, the levels of essential and non-essential metals determined in the sesame seed samples of this work are either lower than the reported data or in good agreement with other studies obtained in the same and other countries. Thus, the amount of $\mathrm{Fe}$ recorded in this study was lower than the concentrations of iron reported by Zebib et al. [41] (102-108 mg/L), Özcan et al. [43] (63.3-254 mg/L) and Obiajunwa et al. [42] (113 mg/L). Zinc is present in appreciable amount in the ranges of $57.9-67.3 \mathrm{mg} / \mathrm{kg}$ indicating higher concentrations when compared to the literature reported from Zebib et al. [41] (42.3-44.5 mg/L) and Özcan et al. [43] (28.3-36.3 mg/L), but lower in concentrations than the values given by Obiajunwa et al. [42] (93.2 mg/L). The concentration of $\mathrm{Cu}(15.3$ to $21.3 \mathrm{mg} / \mathrm{kg})$ determined in this study is also in good agreement with that of the values reported by other researchers such as Obiajunwa et al. [42] (20.4 mg/L) from Nigeria and Özcan et al. [43] (15.1-19.8 mg/kg) from Turkey. Regarding to the non-essential elements $(\mathrm{Cd}$ and $\mathrm{Pb})$, in the present study, the concentrations of cadmium $(0.20-0.27 \mathrm{mg} / \mathrm{kg})$ and lead $(0.08-0.16 \mathrm{mg} / \mathrm{kg})$ were lower compared to the literature data reported [20] (15.7 ng/g for $\mathrm{Cd}$ and $51.6 \mathrm{ng} / \mathrm{g}$ for $\mathrm{Pb})$. The variations 
between the results of this study and literature values may be due to sample size, soil type, genetic variation and environmental factors [28]. Environmental factors such as urban waste, fertilizer use, irrigation, pollution as well as climate variation can also affect the rates of bioaccumulation of metals by plants and their bioavailability [44, 45].

Statistical analysis

The statistical tool F-test is applied for the analysis of variance [46]. To detect whether the difference in means of the concentration of the samples is significant at $95 \%$ confidence level, the one-way ANOVA was applied, and results are summarized in Table 4.

As it is shown in Tables 4, only $\mathrm{Zn}$ and $\mathrm{Cu}$ showed significant differences among the red and white sesame seed samples. These differences could be attributed due to the differences on the nature of soils (soil type), soil $\mathrm{pH}$, and use of different fertilizers, pesticides, agro-climatic conditions, and harvest mechanisms, contamination through air pollution and during transport to the market or at the point of sale [28, 33, 44, 45].

\section{CONCLUSION}

In this study, six sesame samples (three red and three white sesame seeds) purchased from shops of Sheraro town, Northwest Tigray, Ethiopia were analyzed for five selected metals using FAAS using the acid digestion method. Wet digestion method for sesame seed analysis was evaluated through the recovery experiment and a good percentage recovery was obtained in the range of 90 to $120 \%$ for both essential and non-essential heavy metals. The levels of essential and nonessential metals in sesame seed analyzed in this study were in the order of $\mathrm{Zn}(57.9-67 \mathrm{mg} / \mathrm{kg})>$ $\mathrm{Fe}(35.2-43.1 \mathrm{mg} / \mathrm{kg})>\mathrm{Cu}(15.3-21.3 \mathrm{mg} / \mathrm{kg})>\mathrm{Cd}(0.20-0.27 \mathrm{mg} / \mathrm{kg})>\mathrm{Pb}(0.08-0.16 \mathrm{mg} / \mathrm{kg})$. The results of this study indicated that sesame seed contains highest concentration of $\mathrm{Zn}$ in both red and white sesame samples followed by iron and copper, respectively. The concentration of copper and zinc were higher in red sesame seed samples than white sesame seed samples. The statistical analysis by using one-way ANOVA also indicated that there were only significant differences in mean levels of $\mathrm{Zn}$ and $\mathrm{Cu}$ in between the red and white sesame seed samples. This may be due to the differences in physical and chemical composition of soils (soil type), use of different fertilizers, pesticides, agro-climatic conditions, and harvest mechanisms, contamination through air pollution and during transport to the market or at the point of sale. The concentration of essential and non-essential heavy metals in sesame seeds obtained in this study were within the safety limit and thus advisable for consumption as healthy foods.

\section{ACKNOWLEDGEMENTS}

This study was conducted in Mekelle University, Ethiopia. The authors thank Mr. Alem Halefom, Chemistry of Department, Mekelle University for his kind help in sample preparation, Mekelle University for granting this research work and Ezana Analytical Laboratory, Ezana Mining Development PLC, Mekelle, Tigray, Ethiopia, for their constant help of heavy metal analysis.

\section{REFERENCES}

1. Abou-Gharbia, H.A.; Shehata, A.A.Y.; Shahidi, F. Effect of processing on oxidative stability and lipid classes of sesame oil. Food Res. Int. 2000, 33, 331-340.

2. Bikora, G. Oilseed Production and Marketing Situation in Ethiopia, Ministry of Trade, Addis Ababa; 2013. 
3. D'Mello, J.P.F. Food Safety: Contaminants and Toxins, CABI Publishing: Wallingford, Oxon, UK; 2003; p 480.

4. Khan, S.; Cao, Q.; Zheng, Y.M.; Huang, Y.Z.; Zhu, Y.G. Health risks of heavy metals in contaminated soils and food crops irrigated with wastewater in Beijing, China. Environ. Pollut. 2008, 152, 686-692.

5. Maleki, A.; Zarasvand, M.A. Heavy metals in selected edible vegetables and estimation of their daily intake in Sanandaj, Iran. Southeast Asian J. Trop. Med. Public. Health. 2008, 39, 335-340.

6. Sharma, R.K.; Angrawal, M.; Marshal, F.M. Heavy metal in vegetable collected from production and market sites of tropical urban area of India. Food Chem. Toxicol. 2009, 47, 583-591.

7. Krivan, V.; Barth, P.; Morales, A. F. Multielement analysis of green coffee and its possible use for the determination of origin. Microchim. Acta 1993, 110, 217-236.

8. Hashmi, D.R.; Ismail, S.; Shaikh, G.H. Assessment of the level of trace metals in commonly edible vegetables locally available in the markets of Karachi City. Pak. J. Bot. 2007, 39, 747-751.

9. MacPherson, S.; Larochelle, M.; Turcotte, B. A fungal family of transcriptional regulators: The zinc cluster proteins. Microbiol. Mol. Biol. Rev. 2006, 70, 583-604.

10. Orcutt, D. M.; Nilsen, E.T. The Physiology of Plants Under Stress: Soil and Biotic Factors, 1st ed., John Wiley and Sons, 2000; p 683.

11. Winter, W.E.; Bazydlo, L.B.L.; Harris, N.S. The molecular biology of human iron metabolism. Lab. Med. 2014, 45, 92-102.

12. Hawkes, C.; Ruel, M.; Babu, S. Agriculture and health: Overview, themes, and moving forward. Food Nutr. Bull. 2007, 28, S221-S226.

13. Viñas, P.; Pardo-Martinez, M.; Hernandez-Cordoba, M. Rapid determination of selenium, lead and cadmium in baby food samples using electro thermal atomic absorption spectrometry and slurry atomization. Anal. Chim. Acta 2000, 412, 121-130.

14. Kumar, A.; Pastore, P. Lead and cadmium in soft toys. Curr. Sci. 2007, 93, 818-822.

15. Kocak, S.; Tokusoglu, O.; Aycan, S. Some heavy metals and trace essential elements. Detection in canned vegetable foodstuffs by differential pulse polarography. Electronic $J$. Environ. Agric. Food Chem. 2005, 4, 871-878.

16. Gama, E.M.; da Silva, L.A.; Lemos, V.A. Pre-concentration system for cadmium and lead determination in environmental samples using polyurethane foam/Me-BTANC. J. Hazard. Mater. 2006, 136, 757-762.

17. Mittal, S.K.; Goyal, S. Studies on suspended particulate matter in ambient air of an industrial area. Indian J. Environ. Prot. 1995, 15, 839-844.

18. Rudy, M. The analysis of correlations between the age and the level of bioaccumulation of heavy metals in tissues and the chemical composition of sheep meat from the region in SE Poland. Food Chem. Toxicol. 2009, 47, 1117-1122.

19. FEDO, Finance and Economic Development Office, Sheraro Town, Tigray Regional State, Ethiopia, 2015.

20. Fahim, N.K.; Beheshti, H.R.; Janti, S.S.F.; Feiz, J. Survey of cadmium, lead, and arsenic in sesame from Iran. Int. J. Ind. Chem. 2013, 4, 1-3.

21. Tuzen, M. Determination of some metals in honey samples for monitoring environmental pollution. Fresen. Environ. Bull. 2002, 11, 366-370.

22. Gebre, A.; Chandravanshi, B.S. Levels of essential and non-essential metals in Rhamnus Prinoides (Gesho) cultivated in Ethiopia. Bull. Chem. Soc. Ethiop. 2012, 26, 329-342.

23. FAO, Food and Agriculture Organization (FAO) and International Atomic Energy Agency (IAEA), Food and nutrition paper 68: Validation of analytical methods for food control, FAO/UN: Rome; 1998; p 20. 
24. Huber, L. Validation of analytical methods and procedures. Available at: $\mathrm{http}: / /$ www.labcompliance.com/tutorial/methods/default.aspx, 2011. Accessed on May 2011.

25. Thompson, M.; Ellison, S.L.R.; Wood, R. Harmonized guidelines for single laboratory validation of methods of analysis (IUPAC Technical Report). Pure Appl. Chem. 2002, 74, 835-855.

26. Zady, M.F. Z-stats/basic statistics, Z-12: Correlation and simple least squares regression. Available at: Westgard QC website: www.westgard.com/lesson42.htm. Published August 2000. Accessed December 5, 2017.

27. Seno, S.; Ohtake, S.; Kohno, H. Analytical validation in practice at a quality control laboratory in the Japanese pharmaceutical industry. Accred. Qual. Assur. 1997, 2, 140-145.

28. Leshe, S.; Tessema, M. Determination of levels of essential and toxic heavy metals in lentil (Lens culinaris Medik) by flame atomic absorption spectroscopy. AJCE 2014, 4, 16-34.

29. NAS, National Academy of Sciences. Dietary Reference Intakes, 1998. Available at: http:// www.nal.usda.gov/etext/000105.html. Retrieved May 30, 2005.

30 Cooper, G.M. The Cell: A Molecular Approach. 2nd ed., Sunderland (MA): Sinauer Associates. The Central Role of Enzymes as Biological Catalysts 2000. Available at: https://www.ncbi.nlm.nih.gov/books/NBK9921/.

31. Roohani, N.; Hurrell, R.; Kelishadi, R.; Schulin, R. Zinc and its importance for human health: An integrative review. J. Res. Med. Sci. 2013, 18, 144-157.

32. ATSDR, Agency for Toxic Substances and Disease Registry, Toxicological Profile for Zinc and Cobalt, US Department of Health and Human Service, Public Health Service, 1994.

33. Lindsay, W. L. Chemical equilibria in soils. John Wiley and Sons, New York. 1979.

34. Fan, J.; Ding, W.; Chen, Z.; Ziadi, N. Thirty-year amendment of horse manure and chemical fertilizer on the availability of micronutrients at the aggregate scale in black soil. Environ. Sci. Pollut. Res. 2011, 19, 2745-2754.

35. Rutkowska, B.; Szulc, W.; Sosulski, T.; Stępień, W. Soil micronutrient availability to crops affected by long-term inorganic and organic fertilizer applications. Plant Soil Environ. 2014, 60, 198-203.

36. Tchounwou, P.B.; Yedjou, C.G.; Patlolla, A.K.; Sutton, D.J. Heavy metals toxicity and the environment. Exp. Suppl. 2012, 101, 133-164.

37. ATSDR, Agency for Toxic Substances and Disease Registry. Draft Toxicological Profile for Cadmium, Atlanta, GA, 2008.

38.IARC, International Agency for Research on Cancer. Monographs - Cadmium. Lyon, France, 1993.

39.ATSDR, Agency for Toxic Substances and Disease Registry. Toxicological Profile for Cadmium and Nickel, US Department of Health and Human Services, Public Health Service 1999.

40. CODEX General Standard for Contaminants and Toxins in Food and Feed, CODEX STAN, 2010. Available at: http://www.codexalimentarius.net/download/standards/17/CXS 193e.pdf

41. Zebib, H.; Bultosa, G.; Abera, S. Physico-chemical properties of sesame (Sesamum indicum L.) varieties grown in Northern Area, Ethiopia. Agric. Sci. 2015, 6, 238-246.

42. Obiajunwa, E.I.; Adebiyi, F.M.; Omode, P.E. Determination of essential minerals and trace elements in Nigerian Sesame seeds, using TXRF Technique. Pak. J. Nutr. 2015, 4, 393-395.

43. Özcan, M.M.; Harmankaya, M.; Endes, Z. Mineral contents and some physico-chemical properties of some commercial sesame seeds used in halva (sweet) production. Int. J. Farm Alli. Sci. 2013, 2, 115-119.

44. Olajire, A.A.; Ayodele, E.T. Study of atmospheric pollution levels by trace elements analysis of tree bark and leaves. Bull. Chem. Soc. Ethiop. 2003, 17, 11-17. 
45. Johansson, E.; Hussain, A.; Kuktaite, R.; Andersson, S.C.; Olsson, M.E. Contribution of organically grown crops to human health. Int. J. Environ. Res. Public Health 2014, 11, 3870-3893.

46. Skoog, D.A.; West, D.M.; Holler, F.J.; Crouch, S.R. Fundamentals of Analytic Chemistry, 8th ed., Thomson Learning Inc.: USA; 2004; p 151-183. 